\title{
Uneasy Communication in the Authoritarian State
} The Case of Hizb ut-Tahrir in Kyrgyzstan

\author{
IRINA WOLF
}

\section{Introduction}

This article partly draws on the preliminary findings of the project on coverage of Hizb ut-Tahrir organization (further HT) in British, German and Kyrgyz quality newspapers in 2002-2007, and partly on findings of the research thoroughly presented elsewhere (Wolf 2006), which attempted to analyze the coverage of HT in Vechernii Bishkek (further $V B$ ) during 2001-2005. The aim is to illustrate who gets to speak on the pages of $V B$, private yet not independent national Kyrgyz daily, about the controversial organization; what kind of message the general public received about HT from this progovernment newspaper in critical for Kyrgyzstan time; and, to compare and contrast how the same event-a series of suicide bombings in Uzbekistan in 2004 allegedly committed by HT-was covered in $V B$, the British daily The Times, and the German daily Frankfurter Allgemeine Zeitung (further FAZ). Since in Great Britain HT operates legally, as of this writing, and in Germany and Kyrgyzstan the group is prohibited since 2003 it would be crucial to establish how the same event was covered in democratic and nondemocratic societies with different legal status of HT.

For better understanding of aims and findings of the research I first provide a short introduction to the Kyrgyz press, HT in general and HT in Central Asia in particular. Then I explain methodology of research that included quantitative and qualitative methods of media content analysis as well as interviews of four $V B$ journalists. Finally, I provide 
findings pertaining to coverage of HT in $V B$ in 2002-2005; illustrate the differences on how terrorist acts in Uzbekistan were covered in three countries; and, argue that reflection of government position on HT and related matters in its coverage in the Kyrgyz daily is a clear indication of how the authoritarian state exercises its power in determining what the general public would know about the controversial organization and how journalists are constrained by the state and practices of selfcensorship.

\section{On the Kyrgyz Press}

After gaining its independence in 1991, Kyrgyzstan showed signs of opening up its political and economic spheres after 70 years of a totalitarian Soviet rule and, unlike other Central Asian states, was called "the island of democracy" (Anderson 1999). The illusion of democratic development lasted not long and in 1999 Kyrgyzstan entered the zone of "semi-consolidated autocracy" slowly moving towards "consolidated autocracy" (Freedom House cited in: Kulikova 2001: 45). In 2008, according to the Freedom House rating with 1 representing the highest level of democratic progress and 7 the lowest, Kyrgyzstan"s democracy score was 5.93, which was very close to the score of Russia (5.96) (Freedom House 2008). For a number of scholars Kyrgyzstan also remains to be the authoritarian state with the authoritarian media system (Chalaby 2009; McGlinchey 2009; Schatz 2006; Gunn 2003).

Since 1991 the Kyrgyz media have undergone many important transformations, but they are still far from playing a role of a fourth estate as they should in a democratic state. Thus, the number of regularly published newspapers grew from 50 in 1991 to roughly 250 in 2007 with about 1000 being officially registered (Public Association "Journalists" 2008: 18); the monopoly of the only printing house inherited from the Soviet Union was shattered by establishment of a competitive printing house by Freedom House in 2003; the development of internet allowed reaching out audiences and effectively shaping public opinions to the extent of triggering mass discontents (Kulikova and Perlmutter 2007); finally, in May 2007 the government gave up the direct ownership of the public television as well as some media outlets. At the same time as Manzella and Yacher $(2005,439)$ put it:

"the news media of the Kyrgyz Republic [...] has yet to reaggregate fully into the current social system and has yet to become fully a member of the culture of the Western press [...] Trapped as it is within the second stage of a rite of passage, the Kyrgyz Republic media's liminality is manifested by the lack of unified notion, or definition, of what news is, or at least what it should be". 
To understand media markets in the post-Soviet Central Asia, it is crucial to highlight the differences between 'independent", 'privately owned' and 'oppositional' media players in the region. As Allison puts it:

"While many newspapers and media are privately owned, few are independent. The term 'independent' connotes a freedom of thought or lack of bias difficult to find in Central Asia, as media-outlets are extremely pro-governmental because their owners are members of the ruling elite. However, there are several oppositional media outlets in each country, and many of these are owned by oppositional politicians; thus, while their content is not progovernmental, the journalists are still propagandistic tools of certain political figures" (Krimsky cited in: Allison 2006: 94).

Gross and Kenny (2008) also support this argument:

“In Western journalism, 'independence' means that news outlets are free from political, financial, or governmental interference [... I In Central Asia, however, an 'independent newspaper' is often confused with an 'anti-government press'. That is, to be seen as independent a news outlet often believes it must be viewed as opposed to the ruling government, whatever its policies" (Gross and Kenny $2008,56)$.

Thus, media coverage of any issue in Kyrgyzstan remains highly partisan and increasingly sensationalist in nature with the oppositional newspapers practicing what the Western press would regard as "advocacy-style journalism" (Manzella and Yacher 2005: 433); journalists are known "for writing stories that help their publication owners settle political scores" (Kenny and Gross 2008: 521).

The hurdles that media face in Kyrgyzstan from the state include complicated media registration and frequency licensing, censorship and difficult access to information, often persecution for libel and defamation, high taxes, etc. (Allison 2005). The situation is further exacerbated by the low professionalism of journalists and media managers, which has decreased since Soviet times notwithstanding the fact that Europe and the USA spent millions of dollars "in the hopes of developing a Western-style press in Central Asia” (Kenny and Gross 2008: 516). The reasons for that are numerous. Freedman and Chang (2007: 358) highlight "governmental restrains and self-censorship [...] scarce resources for independent news organizations; low salaries for journalists and teachers of journalism; lack of media independence; low public trust in the integrity of the media; lack of public expectations of fairness, accuracy and balance; inadequate training; and the lingering adverse 
impacts of the Soviet model of journalism practice.” Kenny and Gross (Kenny and Gross 2008: 517) add: "it is not authoritarian governments alone that thwart Central Asian journalists, however. Region-wide social norms, based on the traditions of clan and family, urge reporters toward avoiding the critical, nosy behaviour of a journalism grounded in democracy's public accountability. The upshot is simple, if not disturbing: Journalism, the handmaiden and facilitator of Western democracy, is languishing badly in Central Asia”. Finally, as Allison (2006: 106-107) observes:

“Journalists play into authorities' hands by not following laws [...] Journalists are sometimes careless, sometimes intentional in their legal infractions [...] tax evasion is rampant [...] Journalists' materials are frequently libelous by Western standards; frequently lacking facts, they would not stand up in Western courts any more than they do in Central Asia [...] editors and journalists often violate international codes of journalism ethics by taking paid articles, also called 'PR' or 'ordered' articles".

Having shortly introduced Kyrgyzstan, the Kyrgyz media market and hardships that the journalists face in Kyrgyzstan I would like to proceed to introducing Hizb ut-Tahrir.

\section{On Hizb Ut-Tahrir Al Islami}

"Hizb ut-Tahrir al-Islami", translated from Arabic, means the "Party of Islamic Liberation”. A plenty of research papers, articles, reports and books have been written on this organization. Those of International Crisis Group (2002; 2003a; 2003b; 2009), Baran (2004a; 2004b; 2006), Karagianis (2005; 2006a; 2006b; 2007), Maliach (2006a; 2006b), Bakker (2007), Morgan (2007; 2008), Mayer (2004), Siddiqui (2004), Khamidov (2003) are just a small selection of works available to the English speaking community.

In short, HT is a radical Islamist organization or, in their own words, "a political party with Islam as its ideology" (Taquiddin 1999, 23). It was founded in the Jordanian-ruled East Jerusalem suburb in 1952 by Sheikh Taqiuddin al-Nabhani (1909-1977), the Palestinian Islamic legal scholar and political activist, with the aim to liberate Palestine and to re-institute the Islamic Caliphate that was destroyed by Mustafa Kemal (Atatürk) in 1924. While it is estimated that HT operates secretly in around 45 countries (Morgan 2007; Langkjer 2006), it has been banned as an extremist organization in countries throughout Europe (Germany and Nether- 
lands), Central Asia (Kyrgyzstan, Uzbekistan, Tajikistan, Kazakhstan and Turkmenistan), Middle East (Jordan, Syria, Egypt), South Asia (India and Pakistan), Northern Africa (Tunisia and Libya) and in Turkey. In Tajikistan and Russia HT has been banned as a terrorist party (Borogan 2007). While HT has been legalized in May 2006 in Lebanon (Maliach 2006a), as of this writing it is allowed to operate freely in Great Britain, Denmark, the United States, Canada, Australia, the United Arab Emirates, Sudan, and Yemen. Reportedly, in August 2007 HT also re-emerged as a 'new' political player in Palestinian politics, bringing thousands of people on the streets to protest against peace negotiations with Israel; according to some political commentators, HT became a real challenge to the weakening Hamas in the West Bank (Prusher 2008). Whereas some researchers cite HT's headquarters being based in Jordan, the organization legally maintains its office in London that has a tendency to speak on behalf of the whole group and appears to be an ideological nerve centre of the organization (International Crisis Group 2003a; Baran, Starr, and Cornell 2006; Horton 2006; Bergin and Townsend 2007; Mandaville 2007: 266).

One should not, however, perceive HT as a political party in its classical Western meaning. HT is not registered as a party anywhere; it rejects any kind of political structure and refuses to participate in the ruling system of the government. Aiming at reinstituting Islamic Caliphate HT set up a three-stage program. After winning support of a sufficient number of people who believe in the ideas of HT and forming the Party group, HT aims to work with the Muslim community by carrying the message of Islam in all spheres of life. The final stage is re-establishment of the Caliphate, implementation of Islam generally and comprehensively and carrying it as a message to the world (Taquiddin 1999). It is believed that $\mathrm{HT}$ is currently in the second stage of the process at least in the Arab and Central Asian countries (Mayer 2004; Swick 2005).

"The Caliphate will be led by a Caliph appointed by the Muslim community, who will swear allegiance to him. The Caliph will rule according to the Koran and the Sunnah (the practices of the Prophet that have become sanctified customs) and he will be obligated to disseminate Islam through Da'wa (propaganda) and militant Jihad" (Taquiddin quoted in: Maliach 2006a).

Whereas the ideas of Taquiddin appear to be utopian at the modern time, the modernized message of Imran Waheed, the HT chief media advisor in Britain, may sound appealing to masses, especially Muslim immigrant communities in Europe and population of Central Asia, who are longing for justice. 
"Our aim is to re-establish the Islamic Caliphate in the Muslim world. Our vision of the Islamic Caliphate is one of an independent state with an elected and accountable leader, an independent judiciary, political parties, the rule of law and equal rights for minority groups. Citizens of a caliphate have every right to be involved in politics and hold the ruler accountable for his actions. The role of the ruler (caliph) is to be a servant to the masses who governs them with justice" (Paraipan quoted in Whine 2006: 3).

However, the most controversial point about HT is its position on the use of violence in meeting their political ends. Whereas HT claims to be a non-violent organization that rejects terrorist means in achieving its goals, it openly accepts carrying out militant Jihad after the establishment of the Caliphate. Roy once noted that for HT "position against the launching of jihad is purely tactical. The organization believes that the time has not yet come for jihad, but that it is a compulsory duty for any Muslim" (Roy 2004: 256). Meanwhile, HT has been spotted using radical vocabulary of terrorist organizations and praising terrorist acts against the West. Baran went to the extent of claiming that "HT today serves as a de facto conveyor belt for terrorists" because "HT is part of an elegant division of labour. The group itself is active in the ideological preparation of the Muslims, while other organizations handle the planning and execution of terrorist attacks" (Baran 2004a: 11). A number of known more radical spin offs of HT-British al-Muhajiroun and presumably Uzbek Akramiya — certainly lend support to this argument.

\section{On Hizb Ut-Tahrir in Central Asia}

The first reports on HT in Central Asia suggested that after seven decades of Soviet official atheism, Islamic revival filled up the vacuum left behind by the Communist system and allowed such groups as HT easy access to former 'Muslim atheists', a paradoxical expression describing a person in Central Asia, who was born Muslim but has not observed five pillars of Islam (McBrien and Pelkmans 2008: 87). As a Soviet legacy 'Muslimness' was intimately tied to national identity of Central Asians without much of religious content in it (McBrien and Pelkmans 2008: 90; Williams 2004: 130); it changed, however, very quickly. If in 199655.3 percent of ethnic Kyrgyz and 87.1 percent of ethnic Uzbeks in Kyrgyzstan identified themselves as Muslims, then in 200797.5 percent and 99.1 percent of surveyed ethnic Kyrgyz and Uzbeks respectively reported that they were Muslims (McGlinchey 2009: 17). Currently, the scholars argue that it is 
rather bad economic conditions, low political culture, absence of civil society to channel public initiatives, limited excess to power and a wide spread suppression of freedom of speech that played into the hands of HT, helping it to spread its appealing message of justice (International Crisis Group 2003a; Karagiannis 2005; 2006a; 2006b; 2007; Khamidov 2003; Mihalka 2006).

Since HT, while operating in a certain country, attempts to meet the demands of the local population, its activities and spheres of influence in Central Asia differ to a great extent from those in Europe. The core differences lie in HT helping the local populations to overcome economic hardships by setting up mutual aid associations and charity programs (McGlinchey 2009) as well as creating a public space for discussing everyday issues or as Baran puts it, "In a region with limited access to a free press, HT's discussion of everyday issues provides a much needed outlet for news and opinion. HT continuously promotes a message of 'justice' against what many Central Asians view as their corrupt and repressive state structures" (Baran 2004a, 86).

Furthermore, unlike in Europe, in Central Asia the most effective way of recruitment of new members takes place not on the university campuses but in prisons. Since HT is outlawed in all Central Asian counties, it is enough for a local citizen to carry or keep HT leaflets to be arrested and imprisoned. Thus, the common tactic of HT became to get arrested, appeal to sympathy from the local populations, get publicity and start propaganda in prisons. Because traditionally the Central Asian people, especially in Ferghana Valley, have extended family and community sense, an arrest of a person gets quick publicity and it evokes resentment among local population. In this regard Baran commented:

"Since the late 1990s, prisons have become the best places to convert people to radical Islam. The vast majority of inmates deeply resent the establishment. There is also a serious torture problem in Central Asian prisons, especially in Uzbekistan. After enduring such treatment, even the least religious individual is susceptible to HT recruitment efforts. Those who are jailed for small offenses may develop close contacts with HT members while in prison and over time begin to identify with party ideology. By the time they leave prison, former petty criminals can become strong Islamists tied to the larger HT" (Baran 2004a: 86).

Due to the clandestine nature of the party and the tendencies of regimes to exaggerate extremist groups' presence and threat as an excuse for authoritarian responses and policies, the real number of HT members in Central Asia cannot be ascertained (International Crisis Group 2003a: 
1-54; Esposito 2002: 113). Baran et al. (2006: 24) claimed that "HT is numerically strongest in Uzbekistan, with estimates there ranging from 7,000 up to 60,000 members. There are 3,000-5,000 members in both Kyrgyzstan and Tajikistan. The number in Kazakhstan is no more than a few hundred". While the head of the Kyrgyz State Agency on Religious Affairs claimed there were 15,000 HT activists in Kyrgyzstan in 2008, the ICG experts estimate the HT membership in Kyrgyzstan in 2009 to be as much as 7,000-8,000, of whom some 800 to 2,000 could be women (International Crisis Group 2009: 6). Whereas the early reports on HT's activities in Kyrgyzstan stressed their prevalence in the Kyrgyz southern provinces and overwhelmingly ethnic Uzbek membership of the organization ${ }^{1}$ (International Crisis Group 2003a; Karagiannis 2005; Grebenschikov 2002), the more recent studies indicate that HT continuously gains support in the northern part of Kyrgyzstan-at least in Bishkek, Karakol and Ak Terek-and that among the Kyrgyz population (McGlinchey 2009).

\section{Research questions}

RQ1: Who gets to speak on the pages of private yet not independent Kyrgyz newspaper about the controversial organization? RQ2: What kind of message the general public received through this pro-government newspaper? RQ3: How was the same event-suicide bombings in Uzbekistan in 2004-covered in Kyrgyz Vechernii Bishkek, British The Times and German Frankfurter Allgemeine Zeitung?

\section{Methodology}

\section{Sources of Research}

$V B$ is one of a few newspapers in Kyrgyzstan that provide qualitative political information on a regular basis. Published in Russian language since $1974, V B$ has the highest circulation in the country, i.e. 8,000 issues

1 | The higher number of Uzbeks sympathizing with HT compared with those of Kyrgyz people was explained by Grebenschikov (2002) by the fact that Kyrgyzstan was not able to provide the population in the South with print media, textbooks at school, and other channels, from which the Uzbek part of population could generate information in their language. In early 2000s the informational vacuum that could not be filled by the Kyrgyz officials have been filled by the HT leaflets, which contained information on the urgent political, social, and economic developments in the region and the world. 
daily from Monday to Thursday and 62,000 issues on Friday (www.vb.kg); it is the only national newspaper that maintains electronic archives since 1998; during 2001-2005 VB published 215 articles containing at least one reference to HT, which is considerably more than any other qualitative newspaper in the country ${ }^{2}$; and, although this newspaper was privately owned by different people during the timeframe of the research, it always remained loyal to the government. ${ }^{3}$

Additionally, I analyze the articles covering the suicide bombings in Uzbekistan and containing at least one reference to HT that were published in the British daily The Times and the German daily FAZ from March $30^{\text {th }}$ to April $7^{\text {th }}, 2004$. These outlets were selected for the study because in comparison to other similar newspapers in respective countries, they provided the widest coverage of the event mentioning HT.

\section{Timeframe of the Research}

The timeframe of the research-2001-2005-reflect the important years in the Kyrgyz history. Following the terrorist attacks on the USA on September 11, 2001 (further 9/11) the Western allies launched military operations in Afghanistan and Iraq and for that purpose established military bases in Kyrgyzstan and Uzbekistan. 'Combating local Muslim extremists' as part of anti-terrorism measures soon became high on the political agendas of Central Asian regimes, who often found a good excuse to implement their authoritarian policies or to suppress civil oppositions. On March $24^{\text {th }}, 2005$ following the ousting of the former President Akaev from his office, the feeling of democratic change was in the air. There was a hope that the authoritative rule would seize as Kurmanbek Bakiev won presidential elections in July 2005. The articles published in 2001 before $9 / 11$ and in 2005 after March $24^{\text {th }}$ are also

2 | During the same period MSN, a private national newspaper with the second highest circulation after $V B$, published 114 articles that contained reference to HT (www.msn.kg). Slovo Kyrgyzstana, a state owned newspaper that maintains electronic archives only since 2004, published 30 relevant articles in 2004-2005 (www.sk.kg). MSN and Slovo Kyrgyzstana were issued 2 and 3 times per week respectively.

3 | In May 2001 Adil Toigonbaev, the son-in-law of Askar Akaev, at that time the President of the Kyrgyz Republic, allegedly unlawfully appropriated the shares of $V B$ from the private entrepreneur Aleksandr Kim, thus, assuring loyalty of the newspapers to the government. In August 2005, shortly after the forceful change of the Kyrgyz government, Kim legally demanded reconsideration of $V B$ ownership and won the case in the court. As the new government headed by Kurmanbek Bakiev indirectly allowed restoration of Kim's ownership of $V B$, the newspaper again became loyal to the government, that is to Akaev's successor. 
included in the sample in order to establish whether those events had specific influence on HT coverage in $V B$.

\section{Methods of Research}

The sample included every article published in $V B$ from January ${ }^{\text {st }}, 2005$ to December $31^{\text {st }}, 2005$, in which the name 'Hizb ut-Tahrir' was mentioned at least once. The method of research was two-fold-quantitative and qualitative. The classical quantitative analysis (Neuendorf 2002; Stempel 1981) included coding articles on predefined variables 'year', 'author', 'content' and 'tone'. 'Year' variable was encoded in five categories corresponding to the five years of the research timeframe. The 'author' variable first contained the last names of the journalists that were later assigned to six categories: 1) Erlan Satybekov, 2) Shuhrat Abbasov, 3) Ravshan Umarov ${ }^{4}$, 4) Urii Kuzmihyh, 5) others, and 6) not attributed articles. The 'content' variable first contained different thematic descriptions of articles that were later grouped in three categories: 1) 'arrests'-short news articles usually about arrests of the HT members, 2) 'informative'-articles often containing some descriptive information about the HT organization and its activities in the region and abroad, and 3) 'irrelevant' - articles that contained references to HT but were, nevertheless, irrelevant to the HT organization per se.

The 'tone' variable was encoded in three categories that represented sets of terms and information used in relation to HT: 1) neutral, 2) negative, 3) very negative. 'Neutral' articles usually contained little or no descriptive terms and information related to HT; they usually referred to it as the religious or political organization aiming at building a Caliphate. 'Negative' articles contained such reference to HT as 'prohibited organization', 'clandestine organization', 'spreading leaflets of an anticonstitutional content' and 'government is concerned (or alarmed) because of HT activities'. 'Very negative' articles contained such references to the organization as 'religious extremists', 'terrorists', 'radicals', 'religious fanatics', or 'threat to the state and/or people'. A 'positive' category was excluded from the categorization since no article fell into that category.

The qualitative analysis included closer consideration of selected articles as well as semi-structured interviews with four $V B$ journalists who wrote about half of all articles. Interviews with Erlan Satybekov, deputy editor-in-chief of $V B$; Urii Kuzminyh, a $V B$ journalist in charge of crime

4 | Shuhrat Abbasov and Ravshan Umarov are pseudonyms used to protect the respecive authors' identities. 
stories; Shuhrat Abbasov and Ravshan Umarov, VB journalists based in Osh, the southern oblast of Kyrgyzstan-were conducted to explain the quantitative findings and to address the issues of self-censorship of journalists. The inter-coder reliability sample consisted of every $10^{\text {th }}$ article. Simple percent agreement for "content" and "tone" variables was $93.2 \%$.

\section{Findings and Discussion}

RQ1: Who gets to Speak on the Pages of Private yet not Independent Kyrgyz Newspaper about the Controversial Organization?

\section{Journalists}

Of 215 articles, Erlan Satybekov wrote 39 (18.1\%) articles, Shuhrat Abbasov wrote 20 (9.3\%) articles, Ravshan Umarov wrote 23 (10.7\%) articles, Urii Kuzminyh wrote 13 (6.0\%) articles, 12 (5.6\%) were written by Asel Otorbaeva, 15 (7.0\%) by Daniyar Karimov, 13 (6.0\%) by Urii Kuzminyh, 46 (21.4\%) by 29 other authors, and $47(21.9 \%)$ articles were not attributed. As expected, the majority of articles were bylines of journalists rather than routine reports of the press agencies. However, a small circle of journalists wrote about a half of all articles. Satybekov, who has an undergraduate degree in journalism, has lectured in the USA on religious extremism and terrorism in Central Asia, and has traveled to Israel and other countries to learn more about religious extremism. He joined $V B$ in 2001 and was considered by his colleagues to be an expert in questions pertaining to Muslim extremism. Umarov and Abbasov, $V B$ journalists based in Osh, southern part of Kyrgyzstan, are close relatives. They wrote about HT as part of their job covering events in the southern part of the country. These three journalists confirmed that they wrote articles about HT voluntarily, and have never been requested by editor-in-chief to submit additional artilces. Umarov and Abbasov joined VB in 2000. Kuzminyh has been responsible for crime stories since 1995 as he joined $V B$. He saw his job as reporting information he received from law enforcement agencies without adding analytical information. Otorbaeva and Karimov were not interviewed since they were not available at the time of the research phase. 


\section{Law Enforcement Bodies}

It was expected that 47 articles without attribution were either editorials or, perhaps, the names of authors were intentionally not published for certain reasons. Four interviewed journalists said that their names were always published whenever they submitted a publication. Satybekov suggested that absence of attribution was rather a technical problem. According to him, if the same author wrote several articles on the same page, only the last article contained information about the author. This situation might not have been taken into account when the articles were published on the web page. The qualitative analysis of these articles revealed, however, that the overwhelming majority of them were short crime stories about arrests of HT members supposedly provided by law enforcement bodies from the southern regions of the country. Therefore, the voice behind approximately one fourth of all articles on HT-unattributed articles and those written by Kuzminyh—was that of law enforcement officials reporting about criminal offenses of HT members or people allegedly supporting this group.

\section{Hizb ut-Tahrir}

Since HT in Central Asia was stigmatized as 'a terrorist organization' after 2001 and officially banned in 2003 it was expected that the voice of HT itself would hardly be heard from the outlet loyal to the government. However, publication of two lengthy interviews with HT members was de facto giving the floor to extremists to present their views on certain topics that they would otherwise have to spread clandestinely through leaflets. Satybekov's interview of Rahimjan Charikov, the imprisoned HT member was published in $V B$ on September $26^{\text {th }}, 2001$. Satybekov's questions revealed HT's objectives, ideology and reasons of HT being banned in many countries. Charikov's answers presented HT views on the 9/11 terrorist attacks in the USA, relation of the Uzbek president Karimov to Mustafa Kemal Ataturk, and terrorist attacks in Uzbekistan in 1999. Another interview of a HT member was published in $V B$ on July $22^{\text {nd }}, 2005$, i.e. shortly after the presidential elections in Kyrgyzstan. Satybekov wrote the questions and Hamidov conducted the interview with Diler Djumabaev, an entrepreneur and the press-attaché of HT. Several questions of Satybekov provided basic information about HT's membership, strategies, objectives, and ideology. Other questions were specifically aimed at finding out HT's views on the presidential elections in Kyrgyzstan; the March events in Kyrgyzstan that resulted in 
seizure of the government by opposition leaders; on Andijan events in Uzbekistan $^{5}$; the American airbase in Kyrgyzstan; and, the bombings in London. Additional research on HT coverage in VB in 2006 and 2007 revealed that the newspaper provided space for two more interviews with HT members revealing the relations and attitudes of HT to Islamic Movement of Uzbekistan and HT strategy of cooperation with mass media in Kyrgyzstan.

Whereas publication of interview with HT members was seen by Satybekov as an opportunity "[...] to hear the voice on the other side, and at the same time to increase the popularity of the newspaper" (Interview with Satybekov), the second interview was published only three weeks after the Kyrgyz law "On preventing extremist activity" was adopted. According to this law, the mass media were not allowed to spread extremist materials or to undertake extremist activities. Although publication of interviews with HT members openly spreading their message might be seen as giving a platform to extremists, Satybekov stated that neither he nor the $V B$ editor-inchief were approached by state officials.

In comparison, in Germany where the organization is banned since January 2003, the quality press often published very informative articles about HT but never in a form of interview with the German HT members. ${ }^{6}$ In Britain, where the organization is legal, interviews with, refutations by, and articles of the HT members appeared more often. ${ }^{7}$ Thus, notwithstanding the fact that Germany is a democratic state with independent media and HT members were never imprisoned there, the public space was never given directly to HT. In Kyrgyzstan, where people get arrested for merely having an HT leaflet in a pocket, the press, in

5 | In May, 2005 the governmental forces of Uzbekistan massacred several hundreds of protestors in the main square of Andijan, who gathered to protest against the unfair trial over 23 businessmen allegedly belonging to Akramiya group, a spin off of HT.

6 | This statement is based on quantitative analysis of 226 articles that contained at least one reference to $\mathrm{HT}$ and were published in tageszeitung, Frankfurter Rundschau, Süddeutsche Zeitung, Frankfurter Allgemeine Zeitung and Die Welt in 2002-2007. Preliminary findings of qualitative analysis revealed that in 2005 Die Welt published one inerveiw with the Briton of Pakistani origin, who started his Islamist path from joining $\mathrm{HT}$ at the age of 17 (Taseer 2005), and one narrative report of German journalist, who met HT member in Kyrgyzstan shortly before the presidential elections in Kyrgyzstan (Quiring 2005).

7 | This statement is based on quantitative analysis of 396 articles that contained at least one reference to HT and were published in The Daily Telegraph, The Times, The Guardian, The Financial Times and The Independent in 2002-2007. 


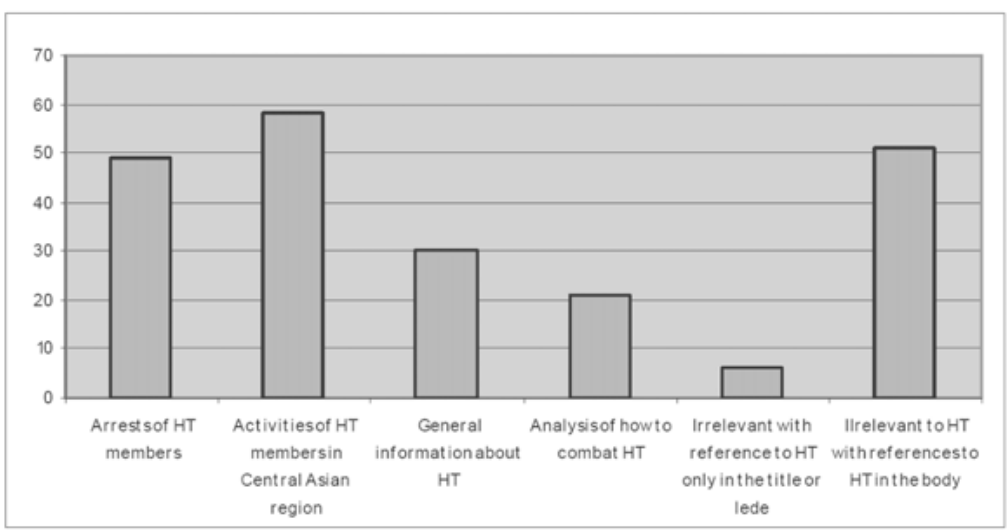

a paradoxical way, allowed HT to speak to the wide audience from its pages.

RQ2: What kind of Message the General Public Received through this Pro-Government Newspaper?

\section{Content}

Of 215 articles, 49 (22.8\%) articles were about arrests of HT members, 109 (50.7\%) articles were 'informative', and 57 (26.5\%) articles were mainly 'irrelevant' to the topic. Of 109 'informative' articles written during five years, $58(53 \%)$ articles were primarily focused on describing activities of HT in the Central Asian region, 30 (17.8\%) articles provided general information about the HT organization, and 21 (12.5\%) articles, apart from providing relevant information on HT, focused on how to combat it. Of 57 articles mainly irrelevant to HT, six (10.5\%) contained references to HT in the titles or ledes of the articles, but nowhere else in the bodies of articles, 51 (80.5\%) contained references to HT in their bodies; 29 (50.95\%) of these 57 articles contained references to HT in the context of terrorism. For graphic presentation see: Figure 1.

The qualitative analysis of articles about 'arrests of HT members' revealed that they were mainly once corresponding to Wright's (1997: 104) term "the front-end/back-end stories". Those are stories that covered arrests of HT members or supporters but usually had no follow up coverage of whether those people were later imprisoned, acquitted or immediately released. Although the number of 'informative articles' was high, 
$V B$ published only 10 articles during 2001-2005 providing exhaustive information on the organization, including historical information on the origin of HT, its ideology and objectives, the types of its activities, reasons why it has been banned in various parts of the world, location of its headquarters, and/or its attitude towards violence and various forms of government. The rest of articles were rather a mixture of use of HT name and a description of HT organization with various degrees of relevance to the focal points of articles. However, as was pointed out earlier, the authors of more than half of mainly irrelevant articles mentioned HT name purely in 'terrorism' context. As expected, coverage of HT was event-driven and the number of articles mentioning the group increased at the times of important international or national events.

The content of articles was carefully weighted and discussed prior to publication by Abbasov and Umarov in Osh. They tried to avoid mentioning such delicate questions as the ethnic identity of HT members. Being ethnic Uzbeks themselves, they explained during interviews that highlighting the Uzbek ethnicity of HT members might have escalated conflict between the Kyrgyz and the Uzbeks and lead to violence. Indeed, although revealing the fact that majority of HT members were at that time the ethnic Uzbeks was not prohibited by any official regulation of the state, the journalists at $V B$ did not write about it. In fact, in 2001 and 2002 there were no references to HT members being Uzbeks. In 2003 in two articles it was mentioned that HT leaflets were in both Kyrgyz and Uzbek languages and in one that HT usually propagated among the Uzbek population in the south. In 2004 there was one reference to an arrested HT member being identified as the Uzbek, and one reference to expropriated HT leaflets in the Uzbek language. In 2005 two articles contained references to HT leaflets published in the Uzbek language.

Umarov said that possession of arms by HT members was another issue to be considered before publication since it had not yet been proved by law enforcement bodies. However, in a number of articles journalists referred both to discovery of arms and to HT, although they did not directly accuse HT of possessing arms. Such references were done obliquely, so that readers could themselves infer that the discovered arms belonged to HT. In this connection, Umarov stated that in VB there were only two people who have a real grasp of HT issues-Satybekov and himself-and some journalists from the north of the country lacking in-depth knowledge of the organization are sometimes too harsh in their references to the group. 


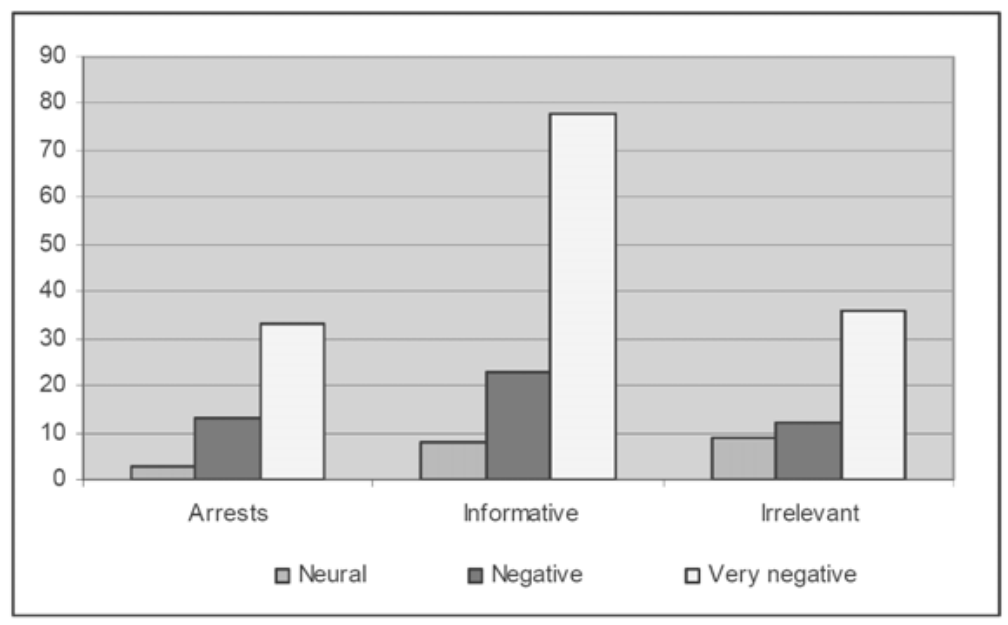

\section{Tone}

Of 215 articles, 20 (9.3\%) contained neutral references to HT, 48 (22.3\%) contained negative and 127 (68.4\%) contained very negative references to HT. Of 49 articles about arrests of HT members, three (6.1\%) articles contained neutral references to HT, 13 (26.5\%) contained negative references and 33 (67.3\%) very negative references to HT. Of 109 informative articles, $8(7.3 \%)$ articles contained neutral references to HT, 23 (21.1\%) contained negative, and 78 (71.6\%) contained very negative references to HT. Of 57 articles mainly irrelevant to HT, 9 (15.8\%) articles contained neutral references to HT, 12 (21.1\%) contained negative, and 36 (63.2\%) very negative references to HT. The relationship between tone and content was not statistically significant. For graphic presentation of data see: Figure 2.

Of 10 articles published in 2001, none of them contained neutral references HT, 1 (10.0\%) contained negative references, and 9 (90.0\%) contained very negative references to HT. Of 48 articles published in 2002, 4 (8.3\%) contained neutral references, $4(8.3 \%)$ contained negative references, and 40 (83.3\%) contained very negative references to HT. Of 50 articles published in 2003, 4 (8.0\%) contained neutral references, $9(18.0 \%)$ contained negative references, and $37(74.0 \%)$ very negative references to HT. Of 55 articles published in 2004, 1 (1.8\%) contained neutral reference, 14 (25.5\%) contained negative references, and $40(72.7 \%)$ 
Figure 3: Tone by year $(N=215)$

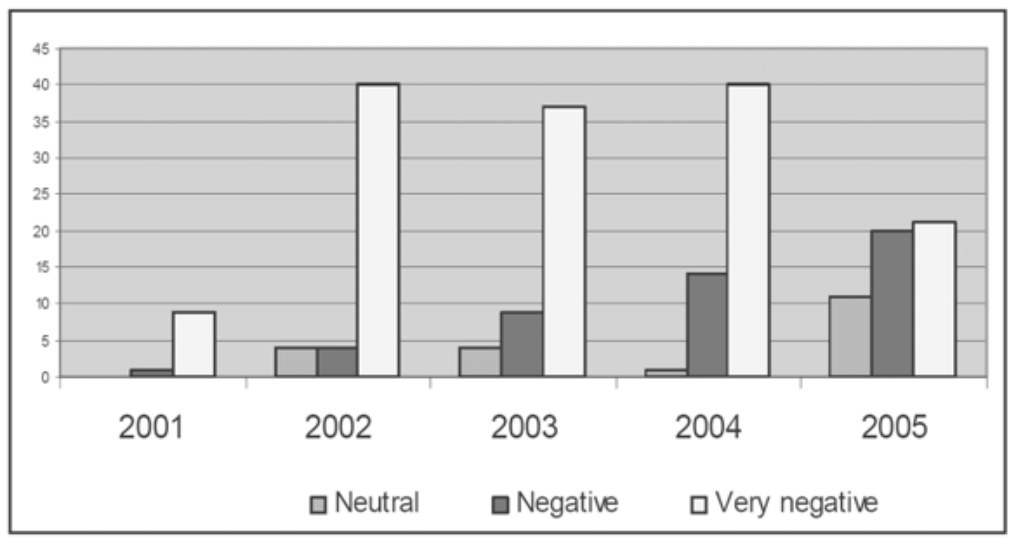

contained very negative references to HT. Of 52 articles published in 2005, 11 (21.2\%) contained neutral reference, 20 (38.5\%) contained negative references, and $21(40.4 \%)$ contained very reference to HT. The relation between variables "tone" and "year" was statistically significant $\left(\chi^{2}(8, N=215)=32,445, p<.01\right)$ with the tone of articles becoming more neutral over years. For graphic presentation of data see: Figure 3.

As mentioned, the category 'positive' tone has been excluded from the coding book because none of the articles contained any positive remarks about HT. Positive attitude toward the organization could have been expressed through mentioning that members of this organization help each other in addressing such issues as unemployment, religious education, funerals, medical care, etc. Satybekov and Umavrov noted that there were some positive aspects about HT that could be covered. They said, for example, that in the southern part of Kyrgyzstan the group was known for charitable activities. There was a case when members organized a big meal for the local population. HT members can count on the financial support from the organization in case of emergency or medical need. The referents said that such information could not, however, be published in $V B$ because "[... ] the end goals of this organization are well known [...]” (Interview with Umarov) and “[...] VB doesn't do promotion of the HT organization" (Interview with Satybekov). To compare, similarly to the Kyrgyz press the German press contained no 
references to any positive activity of HT unlike the British press, in which such references were rare but present. ${ }^{8}$

The assumption that articles became more neutral over years because the number of articles about arrests of HT members has also grown over years was not supported. Although such articles provided little or no information about HT's goals, activities and they were almost never neutral in tone except in 2005, when the articles with neutral tone could be observed regardless of the content of the articles. Apparently, that such difference in coverage of HT could be attributed to the change of the Kyrgyz government and $V B$ directorship in 2005. The four interviewees were of the view that changes of the Kyrgyz government in March 2005, and of the $V B$ directorship in August 2005, influenced neither the content nor the tone of references to HT in $V B$ (Interviews with Satybekov, Abbasov, Umarov, and Kuzminyh). However, the quantitative analysis shows that in $2005 V B$ coverage of HT was more balanced, with the number of the articles written in a "neutral tone" having drastically grown. The qualitative analysis of articles reveals that after the opposition seized power, $V B$ stopped referring to the former opposition having contacts with and support of, the HT organization.

RQ3: How was the same Event-Suicide Bombings in Uzbekistan in 2004-Covered in the Kyrgyz Vechernii Bishkek, British The Times and German Frankfurter Allgemeine Zeitung?

A series of suicide bombings by four women in Uzbekistan in spring 2004 that took lives of more than 40 people was quickly attributed by the Uzbek president Karimov to Islamist terrorists, including the Islamic Movement of Uzbekistan and HT. As VB covered the event, the sources of information used by journalists were primarily those of the press service of the Uzbek president and the Uzbek security service. Such articles obviously contained pure propaganda against the HT group, although the HT's denial of their participation in the bombings was mentioned once. Thus, among other articles there were a reprint of the then president Karimov's statement about the terrorist acts, the report of the Uzbek security services about criminal activities of HT in the region and the interview with the worker of the press service of the Uzbek president.

At the same time the British daily The Times published five articles

8 | Of 396 examined articles from the British press 11 contained remarks about positive activities of $\mathrm{HT}$. 
on the topic that referred to HT: four by Giles Whittell from Tashkent and one by Richard Beeston from Britain. The general tendency was that the authors mentioned blames of the Uzbek government against HT quoting or referring to the Uzbek authorities; HT's denial of having anything to do with this violent event, in particular, and claims of being a peaceful organization in general; HT being legal in Great Britain and them blaming the Uzbek authorities for violence. The authors also referred to human rights organizations stressing how the Uzbek regime exercised routine torture against thousands of Muslim dissidents. Finally, the journalists highlighted several times that the Americans should be embarrassed if they decide to release more than USD 50 million in aid for Uzbekistan that is dependent on human rights improvements in the country. Finally, in the last article on the topic, Whittell (2004) provided a lengthy emotional and detailed report of cases of torture of HT members in the Uzbek prisons, the report that would hardly ever see publication in Kyrgyzstan.

“The woman closes her eyes and explains how it got there. 'He didn't want to confess to praying five times a day because he didn't consider it a crime, so they put long metal spikes in a canvas bag and beat him with it. Still he didn't confess, so they attached electrodes to his abdomen. Still he didn't confess, he didn't die. So he was put into 25 litres of boiling water, in a bath. When his skin was off they poured disinfectant on him. They removed his fingernails and broke his nose and teeth. There was nowhere on his body that was not covered with bruising and signs of torture.' His name was Muzafar Avazov. Hers is Fatima Mukhadirova. She is one of several thousand mothers whose sons and husbands have been taken from them for defying the authority of the flatly unrepentant Government of Uzbekistan [...] Avazov's crime was to have been linked to those radicals; specifically to the Hizb ut-Tahrir sect, which seeks to replace Uzbekistan with an Islamic caliphate under the Sharia Muslim legal system" (Whittell 2004: 6).

The coverage of the event in the German daily $F A Z$ was not as emotional as in The Times. However, similar to the British daily, the frame of the poor records of Uzbekistan in human rights prevailed over the frame of HT being the state's enemy number one. Thus, FAZ covered the bombings mentioning HT in three articles by Markus Wehner from Moscow. Similar to the British coverage, the journalist first illustrated the general situation in places of bombings and referred to the Uzbek authorities blaming HT for violence. He mentioned HT's official response denying the involvement, stressed their official rejection of violence in meeting their goal of Caliphate restoration in Central Asia and quoted HT saying 
that the tyrannical Uzbek regime has staged such events in the past as well in order to supress the legitimate Islamic political opposition. (Wehner 2004a: 7) Wehner mentioned the case of Avazov only shortly and referred to it in the context of records of Human Rights Watch about 7000 sympathizers of HT in the Uzbek prisons and routine torture practices by the Uzbek authorities. Noteworthy is the fact that in sub-title of one of three articles Wehner takes position and blames the Uzbek government for provoking extremism that it fights later on (Wehner 2004b: 10).

It appears that the different legal status of HT in Britain and Germany hardly had any impact on how HT-related event happening abroad was covered by the press. Perhaps the proximity of Kyrgyzstan to Uzbekistan and dependence of the former on the natural resources on the latter influenced on how the controversial issues are portrayed in the press. This proposition, however, only reinforces the argument that the press in Kyrgyzstan is heavily dependent on state politics and willingly or unwillingly supports it on its pages.

\section{Conclusion}

The aim of this study was to establish who was allowed to speak on the pages of private yet not independent Kyrgyz daily about the proscribed organization HT during 2001-2005. Further, it was necessary to establish what kind of message the general public in Kyrgyzstan received from this pro-government newspaper. Finally, it seemed relevant to find out how the same event-suicide bombings in Uzbekistan in Spring 2004was covered in democratic (British and German) and non-democratic (Kyrgyz) societies. It appears that about a half of all articles mentioning HT at least once were written by a small circle of journalists, one of which was editor-in-chief, another was a reporter on crime stories, and two were close relatives based in the Southern part of Kyrgyzstan, who were cross checking material on HT prior to publication in order to avoid controversial or sensitive remarks. Material for about a quarter of all articles was supplied by law-enforcement officials and was mainly about arrests of HT members or sympathizers. Another quarter of articles were mainly irrelevant to HT organization often mentioning it in the context of 'terrorism'. While half of articles were more or less informative on $\mathrm{HT}$, only ten of them provided detailed information about the origin and goals of the organization. The overwhelming majority of articles 
were written in very negative tones, i.e. referring to HT as religious extremists, terrorists, radicals and/or religious fanatics. Whereas not a single positive aspect of HT activities (like charity or employment activities) was covered, even the number of articles that referred to HT in neutral terms-Muslim religious or political organization aiming at building a Caliphate-was very low. The growing number of articles with the neutral references to HT over years was attributed to the changes of the Kyrgyz government and the $V B$ directorship in 2005.

While the personal positions of the journalists seem to have influenced on how they portrayed the HT, the role of the Kyrgyz government in setting the agenda for the private yet not independent newspaper should not be underestimated. The comparison of how VB covered suicide bombings in neighbouring Uzbekistan in spring 2004 with coverage of the same event in the British The Times (where HT is legal) and the German $F A Z$ (where HT is banned) lent support to the argument that coverage of Htrelated issues depends not so much on the legal status of the organization as on independence of media and journalists from state's pressures to write about the banned organization in very negative terms and covering only those aspects of the events that are in line with the wider state's policies. The further investigations and broader analysis of HT coverage in three countries would shed more light on uneasy communication between HT, mass media and states.

\section{References}

Abbasov, S. (pseudonym). Phone interview, May 4 ${ }^{\text {th }}, 2006$.

Allison, O. 2006. Selective Enforcement and Irresponsibility. Central Asia's Shrinking Space for Independent Media. Central Asian Survey 25 (1-2): 93-114.

Anderson, J. 1999. Kyrgyzstan. Central Asia's Island of Democracy. New York: Routledge.

Baran, Z. 2004a. Hizb ut-Tahrir. Islam's Political Insurgency. Washington

D. C.: The Nixon Center.

Baran, Z. editor. 2004b. The Challenge of hizb ut-tahrir. Deciphering and Combating Radical Islamist Ideology. Washington D.C.: The Nixon Center.

Bakker, E. 2007. Exclusion: Who decides-and on what grounds? hizb ut-tahrir and the HDIM. Helsinki Monitor 18 (4): 278-288.

Baran, Z., S. F. Starr and S. E. Cornell. 2006. Islamic Radicalism in 
Central Asia and the Caucasus. Implications for the EU. Sweden: Central Asia-Caucasus Institute \& Silk Road Studies Program, Silk road paper, July 2006.

Bergin, A. and J. Townsend. 2007. Responding to Radical Islamist Ideology. The Case of hizb ut-tahrir in Australia. Australian Strategic Policy Institute. http://www.aspi.org.au/publications/policybrief. aspx?ContentID=117\&pubtype=9. [02/28/2008].

Borogan, I. 2007. Hizb ut-Tahrir. www.agentura.ru. http://www.agentura. $\mathrm{ru} /$ terrorism/hisbuttahrir/ [06/19/2008].

Chalaby, J. K. 2009. Public Communication in Totalitarian, Authoritarian and Statist Regimes. A comparative glance. Paper presented at Totalitarian Communications. Hierarchies, Messages, Codes. University of Konstanz, June $5^{\text {th }}-6^{\text {th }}, 2009$.

Esposito, J. L. 2002. Unholy War. Terror in the Name of Islam. Oxford: Oxford University Press.

Freedman, E. and K.-K. Chang. 2007. Religious news and controversies in Central Asia: A Case Study of a Western 'Christian initiative' News Service. Religion, State and Society 35 (4): 355-371.

Freedom House. 2008. Democracy Rankings 2008 by Regime Type. http: / / www.freedomhouse.org/ template.cfm?page $=438 \&$ year $=2008$ [02/04/2009].

Grebenschikov, I. 2002. The Hizb ut-Tahrir Through the Eyes of Kyrgyz Journalists. Media Insight Central Asia 22 (January 2002): http: //www.cimera.org/en/publications/mica_22.htm [05/23/2008].

Gross, P. and T. Kenny. 2008. The Long Journey Ahead. Journalism Education in Central Asia. Problems of Post-Communism 55 (6): 54-60.

Gunn, T. J. 2003. Shaping an Islamic Identity. Religion, Islamism, and the State in Central Asia. Sociology of Religion 64 (3): 389-410.

Horton, J. 2006. Hizb-ut Tahrir. Nihilism or Realism? Journal of Middle Eastern Geopolitics 2 (3): 71-83.

International Crisis Group. 2002. The IMU and the Hizb-ut-Tahrir. Implications of the Afghanistan Campaign. Osh/Brussels: International Crisis Group, Asia Briefing (11). http://www.crisisgroup.org/library/ documents/report_archive/A400538_30012002.pdf [06/20/2005].

International Crisis Group. 2003a. Radical Islam in Central Asia. Responding to Hizb ut- Tahrir. Osh/Brussels: International Crisis Group, Asia Report (58). http://www.crisisgroup.org/library/doc uments/report_archive/A401032_30062003.pdf [06/20/2005].

International Crisis Group. 2003b. Is Radical Islam Inevitable in Central 
Asia. Priorities for Engagement. Osh/Brussels: International Crisis Group, Asia Report (72).

International Crisis Group. 2009. Women and Radicalisation in Kyrgyzstan. Brussels: International Crisis group, Asia Report (176).

Karagiannis, E. 2005. Political Islam and Social Movement Theory. The case of Hizb ut-Tahrir in Kyrgyzstan. Religion, State and Society 33 (2): 137-149.

Karagiannis, E. 2006a. The Challenge of Radical Islam in Tajikistan. Hizb ut-Tahrir al-Islami. Nationalities Papers 14 (1): 21.

Karagiannis, E. 2006b. Political Islam in Uzbekistan. Hizb ut-Tahrir al-Islami. Europe-Asia Studies 58 (2): 261-280.

Karagiannis, E. 2007. The Rise of Political Islam in Kazakhstan. Hizb ut-Tahrir al Islami. Nationalism and Ethnic Politics 13: 297-322.

Kenny, T. and P. Gross. 2008. Journalism in Central Asia. A Victim of Politics, Economic, and Widespread Self-Censorship. The International Journal of Press/Politics 13 (4): 515-525.

Khamidov, A. 2003. Countering the Call. The U.S., Hizb ut-Tahrir and Religious Extremism in Central Asia. The Saban Center for Middle East Policy at the Brookings Institution 4: http://www. brookings.edu/ /media/Files/rc/papers/2003/07asia_khamidov/ khamidov20030701.pdf [05/14/2008].

Kulikova, S. V. and D. D. Perlmutter. 2007. Blogging Down the Dictator? The Kyrgyz Revolution and Samizdat Websites. International Communication Gazette 69 (29): 29-50.

Kuzminyh, U. Personal interview, Bishkek, May $8^{\text {th }}, 2006$.

Langkjer, B. 2006. Sekter i danmark. Hizb ut-Tahrir, faderhuset, scientologi, In Jiva-behandling. Denmark: Langkjer. http://langkjer.dk/ sekterdk.pdf [05/15/2008].

Maliach, A. 2006a. Islamic Radicalism under the Cover of Political Pragmatism: The Islamic Liberation Party. International Institute for Counter Terrorism: http://www.ict.org.il/index.php?sid=119\&lang= en\&act=page\&id=1386\&str=Hizb\%20ut\%20Tahrir [05/12/2008].

Maliach, A. 2006b. Hizb al-Tahrir al-Islami and the Cartoon Fracas. International Institute for Counter Terrorism: http://www.ict.org.il/ index.phpsid=119\&lang=en\&act=page\&id=5186\&str=Hizb\%20ut\% 20Tahrir [05/12/2008].

Mandaville, P. G. 2007. Global Political Islam. London and New York: Routledge Taylor \& Francis Group.

Manzella, J. and L. Yacher. 2005. The Kyrgyz Republic's Liminal Media. 
Assessing a Journalistic Rite of Passage. Journalism Studies 6 (4): 431-443.

Mayer, J.-F. 2004. Hizb ut-Tahrir. The next al-Qaida, really? Geneva: IUHEI, 4/2004, http://graduateinstitute.ch/webdav/site/iheid/ shared/iheid/514/hizb-tu-tahrir.pdf [03/12/2008].

McBrien, J. and M. Pelkmans. 2008. Turning Marx on his Head. Missionaries, 'Extremists' and Archais Secularists in Postsoviet Kyrgyzstan. Critique of Anthropology 28 (87): 87-103.

McGlinchey, E. 2009. Islamic Rivavalism and State Failure in Kyrgyzstan. Problems of Post-Communism 56 (3): 16-28.

Mihalka, M. 2006. Counterinsurgency, Coutnerterrorism, State-Building and Security Cooperation in Central Asia. China and Eurasia Forum Quarterly 4 (2): 131-151.

Morgan, A. 2007 Hizb ut-Tahrir. Banned elsewhere but not in the US. Why? Islam-Watch: http://www.islamwatch.org/AdrianMorgan/ Why-Hizb-ut-Tahrir-not-Banned-in-US.htm [05/19/2008].

Morgan, A. 2008 Hizb ut-tahrir. An Update. Westminster journal: http: //westminsterjournal.com/content/view/110/30/ [05/18/2009].

Neuendorf, K. 2002. The Content Analysis Guidebook. London: Sage.

Prusher, I. R. 2008 Palestinian Group Sounds like al Qaeda but Forgoes

Violence. The Christian Science Monitor: http://www.csmonitor. com/2008/0122/p01s03wome.html?page=1 [06/19/2009].

Public Association “Journalists”. 2008. Political Extremism, Terrorism and Media in Central Asia. International Media Support.

Roy, O. 2004. Globalised Islam. The Search for a New Ummah. London: Hurst \& Company.

Satybekov, E. 2001. “Chelovek so stekljannymi glazami”[Person with Glass Eyes]. Vechernii Bishkek 185 (7857).

Satybekov, E. and H. Oibek. 2005. "Hizb ut-Tahrir. s glazu na glaz" [Hizb ut-Tahrir. Privately]. Vechernii Bishkek 138 (8812).

Satybekov E. Personal Interview, Bishkek, May $4^{\text {th }}, 2006$.

Schatz, Ed. 2006. Access by Accident. Legitimacy Claims and Democracy

Promotion in Authoritarian Central Asia. International Political Science Review 27 (3): 263-284.

Siddiqui, M. 2004. The Doctrine of Hizb ut-Tahrir. In The Challenge of Hizb ut-Tahrir. Deciphering and Combating Radical Islamist Ideology, edited by Z. Baran, 1-33. Washington D. C.: The Nixon Center.

Stempel, G. H. III. 1981. Content Analysis. In Research Methods in Mass 
Communication, edited by G. H. Stempel, 119-131. Enlewood Cliffs: Prentice-Hall.

Swick, S. 2005. From London to Andijan. The Rising Global Influence of Hizb-ut-Tahrir Among Muslim Youth. Minaret of Freedom Institute: http://208.106.208.252/pdfs/34/finalpapers/SarahSwick.pdf [01/10/2008].

Taseer, A. 2005. Bekenntnisse eines Gotteskriegers. Die Welt (184, August $\left.9^{\text {th }}\right): 10$.

Taquiddin, A.-N.. 1999. The Methodology of Hizb ut-Tahrir for Change. London: al-Khalifah Publications.

Quiring, M. 2005. Eine Wahl zwischen Fanatikern und korrupten Beamten. Die Welt (158, July $\left.9^{\text {th }}\right): 7$.

Umarov, R. (pseudonym). Phone Interview, May $8^{\text {th }} 2006$.

Wehner, M. 2004a. Ein zweiter Tag des Terrors in Usbekistan. Frankfurter Allgemeine Zeitung (77, March 31 ${ }^{\text {st }}$ ): 7.

Wehner, M. 2004b. Überlebenshilfe. Frankfurter Allgemeine Zeitung (78, April $\left.1^{\text {st }}\right): 10$.

Whine, M. 2006. Is Hizb ut-Tahrir Changing Strategy or Tactics? Hudson Institute, Center for Eurasian Policy, Occasional Research Paper 1: http://www.thecst.org.uk/docs/EurasianPaper_Aug42006.pdf [05/12/2008].

Whittell, G. 2004. A Power Ked that is about to Explode. The Times (London) (April $7^{\text {th }}$ ), sec Features.

Williams, B. G. 2004. Crushing Wahhabe Fundamentalists in Central Asia and Caucasus. In New Religious Movements in the $21^{\text {st }}$ Century, edited by P. Lucas and T. Robbins, 129-148. New York and London: Routledge.

Wolf, I. 2006. Hizb ut-Tahrir in Kyrgyzstan. Quantitative Media Content Analysis. Conflict \& Communication on Line 5 (2): http:/ /www.cco. regener-online.de/2006_2/pdf/wolf.pdf.

Wright, S. A. 1997. Media Coverage of Unconventional Religion. Any “Good News" for Minority Faiths. Review of Religious Research 39 (2, Special Issue: Mass Media and Unconventional Religion): 101-15. 
